NBSIR 84-2948

\title{
Field Tests of the Smoke Control System at the San Diego VA Hospital
}

John H. Klote

U.S. DEPARTMENT OF COMMERCE

National Bureau of Standards

National Engineering Laboratory

Center for Fire Research

Gaithersburg, MD 20899

November 1984

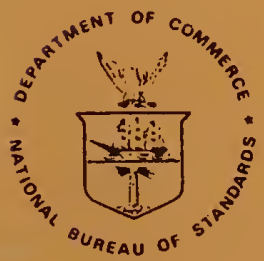

S. DEPARTMENT OF COMMERCE ITIONAL BUREAU OF STANDARDS

100

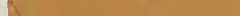



NBSIR 84-2948

FIELD TESTS OF THE SMOKE CONTROL SYSTEM AT THE SAN DIEGO VA HOSPITAL

John H. Klote

U.S. DEPARTMENT OF COMMERCE

National Bureau of Standards

National Engineering Laboratory

Center for Fire Research

Gaithersburg, MD 20899

November 1984

U.S. DEPARTMENT OF COMMERCE, Malcolm Baldrige, Socrotary NATIONAL BUREAU OF STANDARDS. Emeat Ambler. Director 

List of Figures $\ldots \ldots \ldots \ldots \ldots \ldots \ldots \ldots \ldots \ldots \ldots \ldots \ldots \ldots \ldots \ldots \ldots \ldots \ldots \ldots \ldots$ iv

List of Tables $\ldots \ldots \ldots \ldots \ldots \ldots \ldots \ldots \ldots \ldots \ldots \ldots \ldots \ldots \ldots \ldots \ldots \ldots \ldots \ldots$ iv

Abstract $\ldots \ldots \ldots \ldots \ldots \ldots \ldots \ldots \ldots \ldots \ldots \ldots \ldots \ldots \ldots \ldots \ldots \ldots \ldots \ldots \ldots \ldots \ldots \ldots$

1. INTRODUCTION $\ldots \ldots \ldots \ldots \ldots \ldots \ldots \ldots \ldots \ldots \ldots \ldots \ldots \ldots \ldots \ldots \ldots \ldots \ldots \ldots$

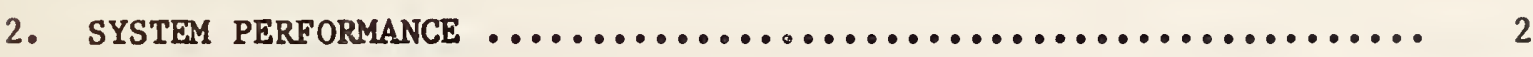

2.1 Pressure Differences ............................ 4

2.2 Open Doors .................................. 5

3. FIELD TESTS $\ldots \ldots \ldots \ldots \ldots \ldots \ldots \ldots \ldots \ldots \ldots \ldots \ldots \ldots \ldots \ldots \ldots \ldots \ldots \ldots \ldots \ldots \ldots \ldots . \ldots \ldots \ldots$

3.1 San Diego VA Hospital ........................... 6

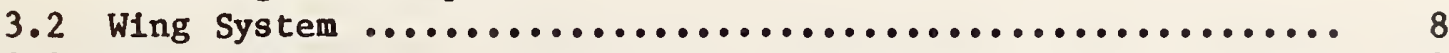

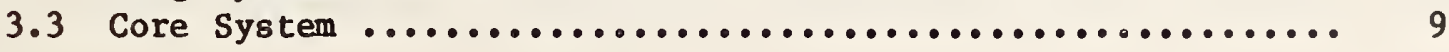

4. DISCUSSION AND RECOMMENDATIONS $\ldots \ldots \ldots \ldots \ldots \ldots \ldots \ldots \ldots \ldots \ldots \ldots \ldots$

4.1 Interstitial space $\ldots \ldots \ldots \ldots \ldots \ldots \ldots \ldots \ldots \ldots \ldots \ldots \ldots \ldots \ldots \ldots . \ldots \ldots$

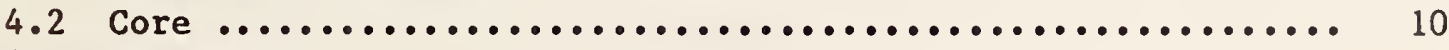

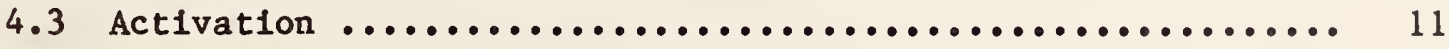

5. ACKNOWLEDGMENTS $\ldots \ldots \ldots \ldots \ldots \ldots \ldots \ldots \ldots \ldots \ldots \ldots \ldots \ldots \ldots \ldots \ldots \ldots \ldots$

6. REFERENCES $\ldots \ldots \ldots \ldots \ldots \ldots \ldots \ldots \ldots \ldots \ldots \ldots \ldots \ldots \ldots \ldots \ldots \ldots \ldots \ldots \ldots \ldots \ldots$ 


\section{LIST OF FIGURES}

Page

Figure 1. San Diego VA Hospital Typical Floor Plan ............ 13

\section{LIST OF TABLES}

Page

Table 1. Smoke control test of San Diego VA Hospital, third floor, south wing

Table 2. Smoke control tests of the San Diego Va Hospital, third floor, core area 
FIELD TESTS OF THE SMOKE CONTROL SYSTEM AT THE SAN DIEGO VA HOSPITAL John H. Klote

\section{Abstract}

The Veterans Administration (VA) has sponsored a project at the Center for Fire Research of the National Bureau of Standards to study smoke control in VA hospitals and to develop new design approaches and methods of acceptance testing. This paper is one report of this ongoing project. It presents the results of a field test on the San Diego VA Hospital.

Key words: air movement; hospitals; interstitial space; pressurization; smoke control; smoke detector.

\section{INTRODUCTION}

Smoke is recognized as the major killer in fire situations [1] * Smoke often migrates to building locations remote from the fire space, threatening life and damaging property. As a solution to the smoke problem, the concept of smoke control has developed in recent years. Smoke control makes use of mechanical fans to produce airflows and pressure differences that can control smoke movement.

This paper is a report of work conducted as part of an ongoing project at NBS sponsored by the U.S. Veterans Administration (VA) to study smoke control in VA hospitals and develop new design approaches and methods of acceptance

\footnotetext{
*Figures in brackets refer to references at the end of this paper.
} 
testing. The smoke control system at the $\mathrm{VA}$ hospital at Bay Pines, Florida has already been tested [2]. In general the Bay Fines system performed well. However, there were some problems and specific recommendations were made to overcome these.

This report describes one day of tests of the smoke control systems at the VA hospital in San Diego, California intended to Identify any obvious problems and if possible recommend corrections. Even though the performance of these systems was disappointing, the cause for the poor performance is identified in this paper and recommendations are made to overcome the problem.

In this paper, the term "smoke" is used in accordance with the ASTM and NFPA definitions which state that smoke consists of the airborne solid and liquid particulates and gases evolved when a material undergoes pyrolysis or combustion $[3,4]$.

\section{SYSTEM PERFORMANCE}

The fire emergency procedures used in hospitals throughout the United States including VA hospitals rely heavily on horizontal evacuation. Each floor of a hospital is divided into a number of zones separated from one another by fire walls and fire doors. Generally, nurses are trained to evacuate any patients from the room of fire origin and then close the door of that room. The patients in the zone which includes the fire room then are evacuated to other zones on that floor. Because of vertical smoke movement, similar horizontal evacuation may be necessary on floors other than the fire floor. Ideally the closed doors between the fire and the occupants retard 
fire spread and smoke movement, allowing sufficient time for fire fighters to extinguish the fire. There is the option for vertical evacuation from these other zones if such an extreme measure is deemed necessary.

In practice, the effectiveness of this approach can be reduced by smoke leakage through building cracks and gaps around doors. The effectiveness of a barrier in limiting smoke movement depends on the leakage paths in the barrier and on the pressure difference across the barrier. The pressure difference depends on stack effect, buoyancy, wind and the heating, ventilation and air conditioning (HVAC) system whether under normal operation or in a smoke control mode.

The concepts of zoned smoke control as described in the ASHRAE smoke control manual [5] can be employed to provide pressure differences and airflows to limit the smoke movement to the zone in which the fire exists.

Because smoke control is a new field, consensus has not been reached as to what constitutes reasonable design parameters. The ASHRAE smoke control design manual lists the following areas for which design parameters must be established:

1. leakage areas

2. weather data

3. pressure differences

4. number of doors open in the smoke control system.

5. airflow 
The reader is referred to the general discussion of leakage areas and weather data provided in the ASHRAE smoke control manual.

\subsection{Pressure Differences}

It is appropriate to discuss both maximum and minimum allowable pressure differences across the boundaries of the smoke control zones. The maximum allowable pressure difference should be a value that does not result in an excessive door-opening force. However, what constitutes an excessive door opening force varies with the application. Section 5-2.1.1.4.3 of the National Fire Protection Association (NFPA) Life Safety Code [6] states that the force required to open any door in a means of egress shall not exceed $222 \mathrm{~N}(50 \mathrm{1b})$. Because of the difficulty of evacuating a disabled patient and because exposure to smoke can adversely affect a person's physical ability, a value lower than $222 \mathrm{~N}$ (50 1b) seems appropriate. For a door opening force of $111 \mathrm{~N}(25 \mathrm{1b})$ and a force of $31 \mathrm{~N}(7 \mathrm{~b})$ to overcome the door closer, a door $1.12 \mathrm{~m}$ (44 in) wide and $2.13 \mathrm{~m}(7 \mathrm{ft}$ ) high would have a maximum allowable pressure difference of $63 \mathrm{~Pa}\left(0.25\right.$ in $\left.\mathrm{H}_{2} \mathrm{O}\right)$. For purposes of discussion here, this will be used as the maximum allowable pressure difference.

In this paper, the criterion for a minimum allowable pressure difference is that no smoke leakage* shall occur from the smoke zone (one in which there is a fire) to an adjacent zone. The smoke control system must produce sufficient pressure differences so that it is not overcome by the forces of wind, stack effect, or buoyancy of hot smoke.

\footnotetext{
* It is obvious that a smoke control system can meet its objectives of reduced fire deaths, injuries and property damage due to smoke, even if a small amount of smoke infiltrates the protected areas.
} 
A minimum pressure difference of $5 \mathrm{~Pa}\left(0.02\right.$ in $\left.\mathrm{H}_{2} \mathrm{O}\right)$ suggested in the ASHRAE manual (section 2.9.2) for sprinklered spaces is used in this paper as the minimum pressure difference to overcome the effects of buoyancy of smoke for sprinklered hospital spaces. A minimum pressure difference of $25 \mathrm{~Pa}(0.10$ in $\mathrm{H}_{2} \mathrm{O}$ ) suggested in the ASHRAE manual for smoke control systems intended to withstand intense fires is used in this paper as the minimum pressure difference to overcome the effects of buoyancy of smoke for unsprinklered hospital spaces. The smoke control system should be designed to produce the appropriate minimum pressure under design conditions of wind and stack effect with a broken window in the fire compartment. Such an analysis can be performed by the computer program described in the ASHRAE design manual.

\subsection{Open Doors}

During a fire, the doors in boundaries of a smoke zone w11l be closed except for short intervals when a person is leaving or when a rescuer or fire fighter enters the smoke zone. Under these conditions, smoke infiltration into the protected zones is significantly less than when doors are held open. For purposes of discussion in this paper, smoke leakage through such intermittently open doors is considered insignificant. However, the airflow produced by the smoke control system sometimes can be sufficient to hold doors partially open as occurred at the Bay Pines VA Hospital [2]. This was not the case at the San Diego VA Hospital. 


\subsection{San Diego VA Hospital}

The San Diego VA Hospital consists of six stories, each with an interstitial space above for distribution of heating, ventilation, airconditioning, plumbing and electrical systems. Air handling equipment (fans, coils, filters, etc.) is also located with the interstitial space. This space varies in height from $2.4 \mathrm{~m}$ ( 6 to $8 \mathrm{ft}$ ) and is separated from the floor below only by the suspended ceiling system. Except for a few high risk areas, this nsists of six stories each with an interstitial space above for distribution of heating, ventilation, air-conditioning, plumbing and electrical systems. Air handling equipment (fans, colls, filters, etc.) is also located with the interstitial space. The interstitial space is approximately $2.4 \mathrm{~m}$ (8 $\mathrm{ft}$ ) in height and is separated from the floor below by only suspended ceiling system. Except for a few high risk areas, this hospital is unsprinklered.

The top five floors consist of four wings and a central core which contains the elevators as shown in figure 1. Each wing is served by its orn HVAC system which is, for the most part, a $100 \%$ outside air system. The central core is supplied with air from all the wings but exhausted by a single fan located in the penthouse. The smoke control system is arranged such that each floor of each wing is a separate smoke control zone. In the event of a fire in one of the wings, the HVAC system, controlled by a computer, is put in the following smoke control mode: 
1. The supply fan to the zone in which the fire exists (smoke zone) is shut off.

2. Exhaust fans serving all other wings of the fire floor are shut off, and exhaust fans serving the wings directly above and below are also shut off.

Thus air is being exhausted from the smoke zone and other zones are being pressurized. The intent is that smoke movement will be limited to the zone in which the fire exists. This system is activated by pull boxes, water flow switches, heat detectors and duct smoke detectors.

When the system was designed no provisions were made for a fire in the central core (see figure 1). However, a core smoke control system is currently being installed which will operate as follows:

1. Dampers in the duct supplying the core close to shut off supply air to the core area on the floor (smoke zone).

2. Dampers in the core exhaust system close on all other floors.

3. Exhaust fans serving the wings of the top five floors are shut off.

This system also is intended to be activated only by pull boxes, water flow switches, heat detectors and smoke detectors. The dampers for the system were all installed so that operation could be simulated by manually controlling the dampers. 


\subsection{Wing System}

The third floor south wing was tested as the smoke zone in order to compare the system performance with NBS measurements of the same system which were made approximately eight years earlier [7]. The test results from the earlier study for normal smoke control operation and the results from this study are 1isted in table 1. In the previous study the smoke control system produced only $5 \mathrm{~Pa}\left(0.02\right.$ in $\left.\mathrm{H}_{2} \mathrm{O}\right)$ from the core to the south wing, while the current tests produced $10 \mathrm{~Pa}\left(0.04\right.$ in $\left.\mathrm{H}_{2} \mathrm{O}\right)$. This increase, possibly due to modifications in construction, still results in a pressure difference considerably below the minimum pressure difference for an unsprinklered space.

It was hypothesized that this poor performance was due to exceptionally high leakage from the outside to the south wing. This would result in exhaust air being pulled directly from the outside rather than through the core. Leakage areas were evident in the gaps around the exterior six doors of this wing to the outside balcony. These door gaps were sealed with tape and the system was retested (table 1). The pressure difference from the core to the south wing had increased to $12 \mathrm{~Pa}\left(0.05\right.$ in $\left.\mathrm{H}_{2} \mathrm{O}\right)$ which was still below the desired minimum pressure difference but which indicated that at least some of the poor performance was due to high leakage from the outside.

The suspended ceiling separating the building space of the south wing and its interstitial space had several obvious openings at poorly fitting tiles and missing tiles in addition to the normal cracks between tiles and suspension system. In addition, the interstitial space had several vents directly to the outside. Because it was suspected that air flow from the outside 
through these vents and then through the suspended celling reduced the smoke control system effectiveness, these vents were blocked off and the system retested. This increased the pressure difference from the core to the south wing to $15 \mathrm{~Pa}\left(0.06\right.$ in $\left.\mathrm{H}_{2} \mathrm{O}\right)$.

\subsection{Core System}

The core smoke control system was tested on the third floor and the test results are listed in table 2. In these tests the pressure differences between all the wings and the core are important. The low pressure differences across these boundaries in the normal smoke mode (table 1) was probably due to insufficient exhaust capacity. Inspection of the core indicated that it was relatively air tight to the outside as compared to the south wing. This led the testing team to suspect that if one or more paths for air from the core to the outside existed, then increased flow from the wings would result in increased pressure difference. To test this hypothesis three of the windows in the core were opened and the pressure differences increased from a range of 5 to $7 \mathrm{~Pa}\left(0.02\right.$ to 0.03 in $\left.\mathrm{H}_{2} 0\right)$ to a range of 12 to $20 \mathrm{~Pa}(0.05$ to 0.08 in $\mathrm{H}_{2} \mathrm{O}$ ).

\section{DISCUSSION AND RECOMMENDATIONS}

Currently an englneering study is underway to examine alternatives to improve fire safety at the San Diego VA Hospital. The minimum pressure difference to which a smoke control system should perform will depend on whether spaces are to be sprinklered. The following discussion and recommendations are provided in the hope that they will be useful for this englneering study. 
The vents from the interstitial space to the outside should be closed. This will improve the performance of the smoke control system in the third floor south wing, and probably in all the other wings because of similar construction. Further with the vent open it is questionable whether the interstitial space exhaust is capable of preventing smoke downflow through the suspended ceiling from the interstitial space. Smoke from a fire in a building space can flow up through the ceiling system into the interstitital space, cool and then flow down through the ceiling into a remote space thereby causing hazardous conditions. It has been shown by Klote [8] that this hazard can be prevented by use of an interstitial space exhaust at a rate of two air changes per hour, provided that the leakage area between the interstitial space and the outside is relatively small. The exhaust capacity of the interstitial space should be reexamined. If it is below two air changes, it should be increased to, and possibly above this value if improved smoke control system performance is desired.

\subsection{Core}

The system being installed in the core should be reevaluated because of its poor performance. Its capacity can be increased by increasing the exhaust capacity or by the addition of vents from the core directly to the outside. Such vents should be located on at least two opposite outside walls to minimize any adverse effects of the wind. 


\subsection{Activation}

Smoke control system activation by pull boxes should be reevaluated.

Pull boxes activate the smoke control zone in which they are pulled. However, It is conceivable that they might be pulled in a zone other than the fire zone, resulting in the system aiding smoke spread rather than preventing it. If possible, activation should be by means of open area smoke detectors, sprinkler water flow, or both. Activation only by duct detectors is not recommended because of the long response time and the maintenance problems associated with these units.

\section{ACKNOWLEDGMENTS}

Thanks are due to the staff of the San Diego VA Hospital for their aid and cooperation during these tests. Appreciation is specifically expressed to William Schmidt and Lyle Clark of the Veterans Administration.

\section{REFERENCES}

[1] Ber1, W.G. and Halpin, B.M., Human Fatalities from Unwanted Fires, Johns Hopkins APL Technical Digest, Vol. 1, No. 2, p. 129-134, 1980.

[2] Klote, J.H., Field Tests of the Smoke Control System at the Bay Pines VA Hospital, Nat. Bur. Stand. (U.S.), NBSIR 84-2868, May 1984.

[3] Annual Book of ASTM Standards, Part 18, ASTM E176-80, American Soclety for Testing and Materials, Philadelphia, PA, 1980.

[4] Standard for the Installation of Air Conditioning and Ventilating Systems, NFPA 90A-1981, National Fire Protection Association, Inc., Quincy, MA, 1981 .

[5] Klote, J.H. and Fothergi11, J.W., Design of Smoke Control Systems for Buildings, American Society of Heating, Refrigerating, and A1rConditioning Engineers, Atlanta, GA, 1983. 
[6] Code for Safety to Life from Fire in Buildings and Structures, NFPA 101-1981, Quincy, MA, National Fire Protection Assn., 1981.

[7] Fung, F.C.W. and Zile, R.H., Test and Evaluation of the Smoke Control Capabilities of the San Diego Veterans Administration Hospital, Nat. Bur. Stand. (U.S•), NBSIR 77-1225, Apri1 1977.

[8] Klote, J.H., Smoke Movement Through a Suspended Ceiling System, Nat. Bur. Stand.(U.S.), NBSIR 81-2444, Feb. 1982 . 


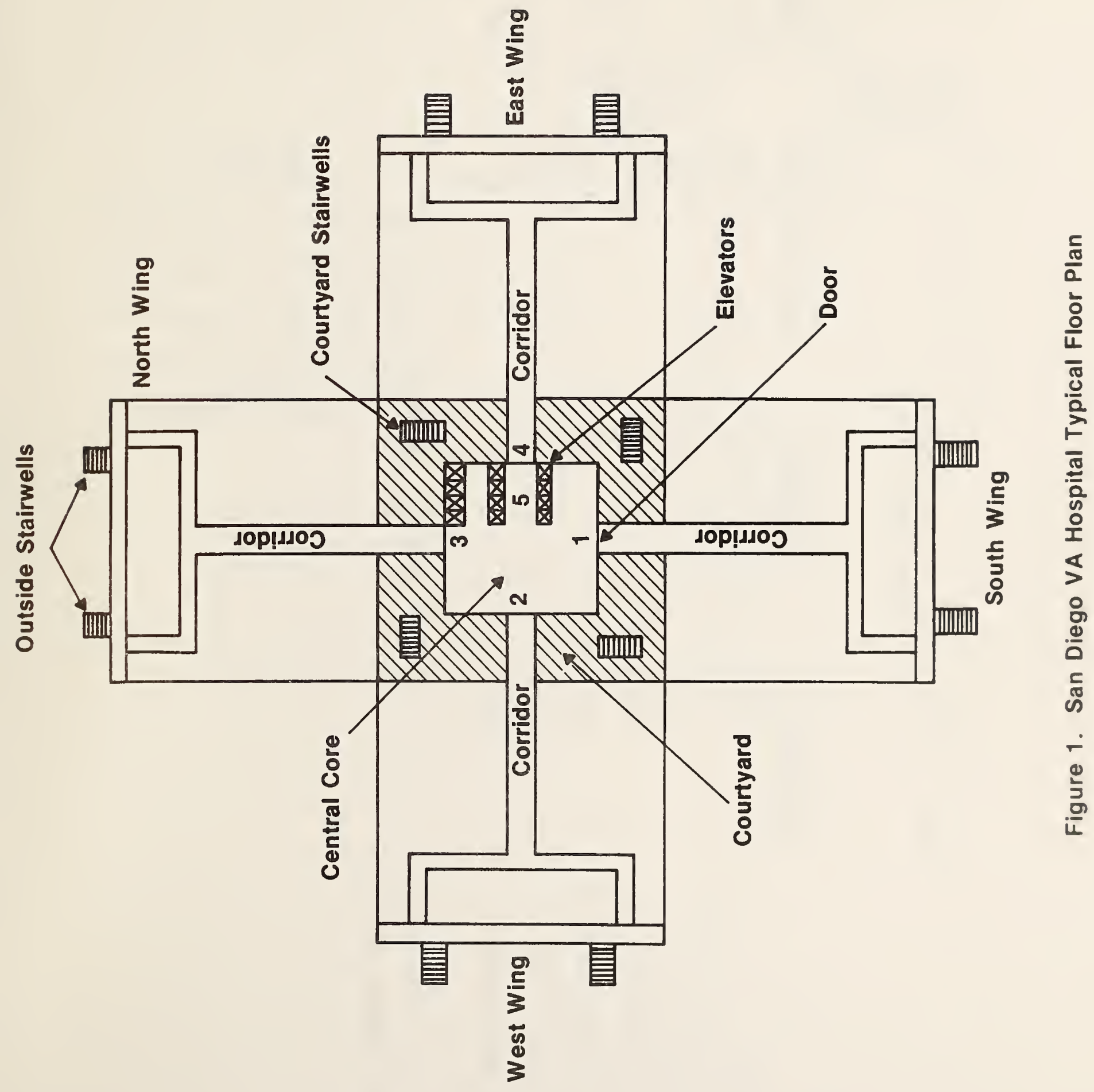




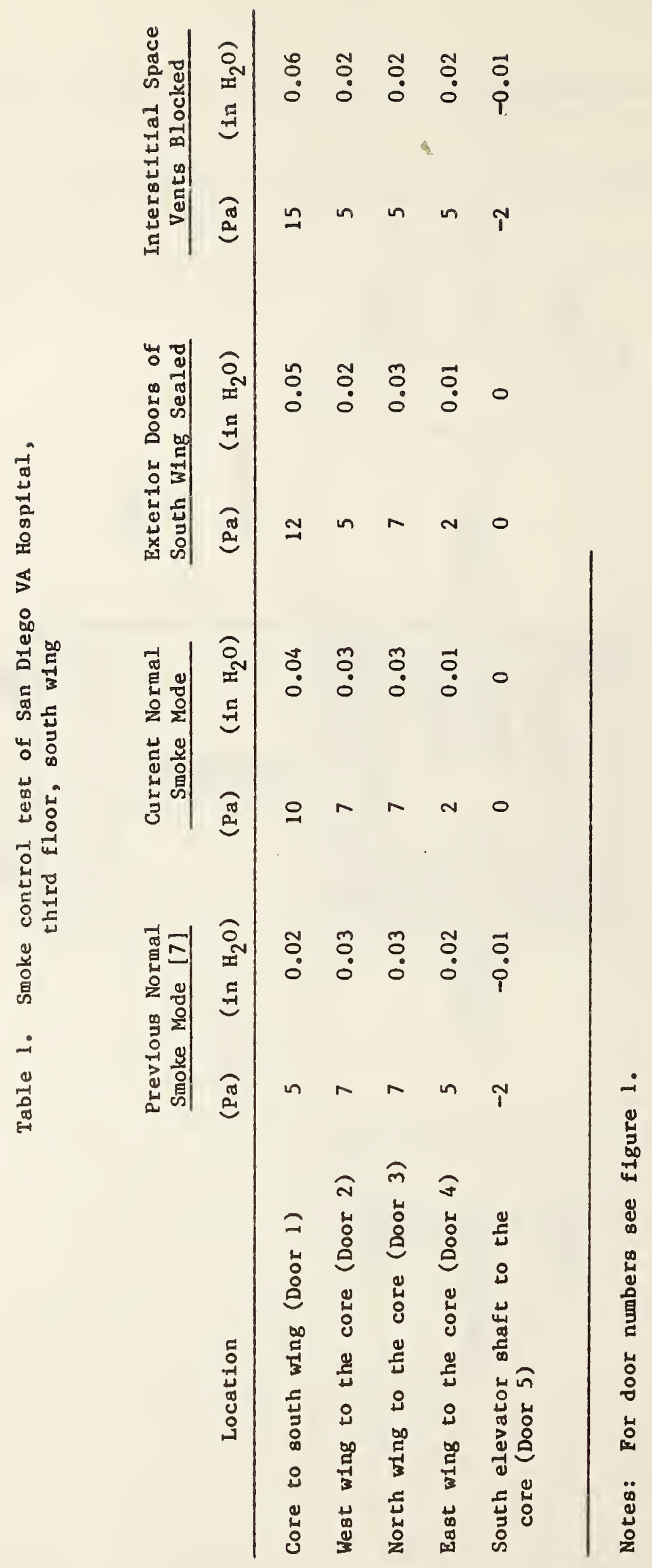


Table 2. Smoke control tests of the San Diego VA Hospital, third floor, core area

\begin{tabular}{lcccc} 
Location & $\begin{array}{c}\text { Normal Smoke } \\
\text { Mode }\end{array}$ & $\begin{array}{c}\text { Three Open } \\
\text { Core Windows }\end{array}$ \\
\hline South wing to the core (Door 1) & 5 & 0.02 & 12 & 0.05 \\
West wing to the core (Door 2) & 7 & 0.03 & 20 & 0.08 \\
North wing to the core (Door 3) & 7 & 0.03 & 12 & 0.05 \\
East wing to the core (Door 4) & 7 & 0.03 & 12 & 0.05 \\
South elevator (Door 5) & 0 & 0 & 7 & 0.03
\end{tabular}


NBS.114A (REV. 2.8C)

U.S. DEPT. OF COMM.

1. PUBLICATION OR

2. Performing Organ. Report Noy 3. Publication Date

BIBLIOGRAPHIC DATA

SHEET (See instructions) REPORT NO. NBSIR 84-2948

November 1984

4. TITLE AND SUBTITLE

Field Tests of the Smoke Control System at the San Diego VA Hospital

5. AUTHOR(S)

Dr. John H. Klote

6. PERFORMING ORGANIZATION (If joint or other than NBS, see instructions)

7. Contract/Grant No.

NATIONAL BUREAU OF STANDARDS

DEPARTMENT OF COMMERCE

8. Type of Report \& Period Covered

WASHINGTON, D.C. 20234

9. SFOHSOKHIG ORGANIZATION NAME AND COMPLETE ADDRESS (Street, CitY, Stote, ZIR)

10. SUPPLEMENTARY NOTES

Document describes a computer program; SF-185, FIPS Software Summary, is attached.

11. ABSTRACT (A 200-word or less factual summary of most significant information. If document includes a significant bibliography or literature survey. mention it here)

The Veterans Administration (VA) has sponsored a project at the Center

for Fire Research of the National Bureau of Standards to study smoke

control in VA hospitals and to develop new design approaches and methods

of acceptance testing. This paper is one report of this ongoing project.

It presents the results of a field test on the San Diego VA Hospital.

12. KEY WORDS (Six to twelve entries; alphabetical order; capitalize only proper names; and separate key words by semicolons) air movement; hospitals; interstitial space; pressurization; smoke control; smoke detectors

13. AVAILABILITY

X Unlimited

For Official Distribution. Do Not Release to NTIS

Order From Superintendent of Documents, U.S. Government Printing Office, Washington, D.C. 20402.

X] Order From National Technical Information Service (NTIS), Springfield, VA. 2216I
14. NO. OF

PRINTED PAGES

18

15. Price

$\$ 7.00$ 

